\author{
Andrii V. Balendr \\ PhD of Pedagogical Sciences, Associate Professor, \\ Associate Professor of the English Language Department of Foreign Languages and Humanities Faculty \\ National Academy of the State Border Guard Service of Ukraine named after Bohdan Khmelnytskyi, \\ Khmelnytskyi, Ukraine \\ ORCID ID 0000-0003-4610-2830 \\ rbalen@i.ua
}

\begin{abstract}
Vasyl O. Korolov
Khmelnytskyi, Ukraine

ORCID ID 0000-0002-8342-7557

docentpvu@i.ua
\end{abstract}

$\mathrm{PhD}$ in Law, Associate Professor of the Special Discipline Department

National Academy of the State Border Guard Service of Ukraine named after Bohdan Khmelnytskyi,

Oleksandr V. Adamchuk

PhD of Psychological Sciences, the Head of the Border Security and Protection Faculty

National Academy of the State Border Guard Service of Ukraine named after Bohdan Khmelnytskyi, Khmelnytskyi, Ukraine

ORCID ID 0000-0003-0280-6334

alexadamchuk@ukr.net

\author{
Anatolii V. Iakymchuk \\ $\mathrm{PhD}$ of Psychological Sciences, Lecturer of the Border Guard Service Tactics Department \\ National Academy of the State Border Guard Service of Ukraine named after Bohdan Khmelnytskyi, \\ Khmelnytskyi, Ukraine \\ ORCID ID 0000-0002-2729-8201 \\ anatoliy_yakimch@ukr.net \\ Serhii V. Sinkevych \\ $\mathrm{PhD}$ of Pedagogical Sciences, Associate Professor, \\ Associate Professor of the General Military Disciplines Department \\ National Academy of the State Border Guard Service of Ukraine named after Bohdan Khmelnytskyi, \\ Khmelnytskyi, Ukraine \\ ORCID ID 0000-0001-5838-2177 \\ sinkevich76@i.ua \\ Ihor H. Bloshchynskyi \\ Doctor of Pedagogical Sciences, Professor, \\ Head of the English Translation Department, Faculty of Foreign Languages and Humanities \\ National Academy of the State Border Guard Service of Ukraine named after Bohdan Khmelnytskyi, \\ Khmelnytskyi, Ukraine \\ ORCID ID 0000-0003-1925-9621 \\ i.bloshch@gmail.com
}

\title{
BORDER GUARDS' DISTANCE LEARNING DEVELOPMENT IN THE EUROPEAN UNION COUNTRIES
}

\begin{abstract}
The research reveals the peculiarities of the Distance Learning (DL) development in the framework of border guards training in the European Union (EU) countries. Theoretical and practical concepts, modern stage and peculiarities of border guards' DL development were substantiated in the article. The special attention was paid to possibilities of educational web platforms, which are widely utilized in the training of personnel of the border guard agencies, namely: Web Platform Virtual Aula of the FRONTEX Agency; E-Net Web Platform of the CEPOL (The European Police College); EU Coast Guard Functions Training Portal (CGFTP); ILIAS Learning Platform of the EU Mission EUBAM (EU Border Assistance Mission to Moldova and Ukraine); Connect \& Learn platform of the UNHCR (The Office of the United Nations High Commissioner for Refugees); Global eLearning Program of the UNODC (United Nations Office on Drugs and Crime). The authors have also conducted the comparative analysis of DL courses of educational platforms with border guard components in the EU countries, which showed that the platform with the biggest number of border guard-oriented courses is Virtual Aula platform of FRONTEX Agency. Suggestions and proposals on DL development and prospective directions
\end{abstract}


based on the experience gained during DL introduction into the system of the border guards' training system supported by the survey results are given in the conclusion of this article in order to facilitate the improvement of border guards' DL systems in the EU countries. The prospects of the border guards' DL system development are based on 5 key factors: aligning all DL training courses to the Sectoral Qualification Framework and Common Core Curricular for border guarding: unification of the skills and knowledge of European border guards; enhanced use of the Internet and social media; introduction of common educational web-platforms; organizing specialized training for the specialists in DL use and management, and developing common eLearning tools and programs.

Keywords: border guards' training; distance learning; educational web-platforms; European Union countries.

\section{INTRODUCTION}

The problem setting. As a force contributing to social and economic development, DL is one of the most rapidly growing fields of education and training nowadays. It is fast becoming an accepted and indispensable part of the main stream of educational systems in both developed and developing countries, with particular importance for the latter. In efforts to meet the new and changing demands for training, DL may be seen as an approach that is at least complementary and under certain circumstances an appropriate substitute for the faceto-face methods that still dominate many educational systems [1]. Today DL gives everybody an opportunity to study individually, regardless of time and place; it is the realization of lifelong learning principles. There is growth in the number of students enrolled in the DL courses, as well as universities using this form of education in the learning process [2].

Therefore, the issue of using possibilities of DL for modernization of the European lawenforcement agencies personnel training system, which includes border guard authorities as well, has recently become a key one. Besides each country's own efforts to organize the DL professional training system, some of the European organizations and agencies have done a lot to provide common and harmonized DL training courses via specialized educational webplatforms.

The analysis of recent studies and publications. The variations of using eenvironment and the phenomenon of introducing eLearning as an innovative approach to border guards' learning has developed very rapidly, hence it is important to analyze and share the best practices of eLearning approaches and models currently implemented [3]. Whether asynchronous, synchronous, or mixed models of delivery, the advantages of eLearning systems based on Internet technology include: reliable, standard-based technology platform; broad reach and portability; relatively low technology costs for the learner; capability to update training content or curriculum quickly and cost-effectively; and capability to create rich, highly interactive learning environments through integration of multiple media [4]. Some Ukrainian scholars researched the use of information and communication technologies in foreign languages training of the border guards in the EU countries [5].

The prospects of developing e-learning at the State Border Guard College in Latvia have been studied by the contemporary scientists [3]; modern educational and informationalcommunication technologies in the field of military education were revealed in the works of Ukrainian and Belarus authors $[2 ; 6 ; 7]$. However, the peculiarities of the border guards' DL development in the EU countries have not been covered yet. Therefore, the purpose of the article is to analyze the DL development in the framework of border guards training in the EU countries, based on platforms: e-Net web platform of the CEPOL; Web Platform Virtual Aula of the FRONTEX Agency; CGFTP; ILIAS Learning Platform of the EU Mission EUBAM; Connect \& Learn platform of the UNHCR; Global eLearning Program of the UNODC; and outline prospects of its development. 


\section{METHODOLOGY OF RESEARCH}

In order to resolve the tasks of the article the following methods of research were used: theoretical and critical, logical analysis of pedagogical, psychological and methodological literature, normative legal documentation - to determine the current state of development of the problem of the border guards' DL development in the EU countries; synthesis, comparison, comparative study of the corresponding concepts, trends, classification - to clarify and substantiate the essence of the problem, the substantiation and formulation of prospective directions of the border guards' DL development in EU countries; empirical pedagogical observation, collection and generalization of data, analysis of curricula, typical educational programs, analysis of educational tools and methodological aids, educational activities utilized in various learning environments of the border guard educational institutions and web-platforms. The data was collected using triangulation: desk research of the educational web-platforms, quantitative analysis of the EU Border Guard Agencies' DL, comparative study of DL courses of educational platforms with border guard components in the EU countries.

\section{RESULTS AND DISCUSSION}

\subsection{The Modern Stage of EU Border Guard Agencies' DL development}

Globalization, which affects European border guard agencies, development of the personnel mobility and interoperability require significant changes in the educational process of the border guard educational institutions. In the view of the nowadays rapidly changing cross-border challenges the modern border guards training and education should be based on the philosophy of contemporary law enforcement activity and the concept of life-long learning.

Common strategic goals and directions for the development of the professional training of the border guard authorities of the EU countries are determined during the annual conference of law enforcement agencies of the EU countries, under the auspices of the FRONTEX Agency, which also involves the Ukrainian Border Guard Service. In 2017, the conference entitled "Educational Technologies in the Border Guards' Training" was held in Warsaw, Poland. The conference was attended by the National Coordinators for the border guards' training in the EU member states, the associated countries of the Schengen agreement and representatives of international law enforcement organizations (INTERPOL, CEPOL, UNHCR), representatives of the FRONTEX partner academies.

The participants of the conference agreed that in order to ensure the highest extent of outreach and to implement cost-effective ways of educational development and training provision, emphasis should be given to collaboration and learning via means of new technologies. This allows better synchronization with the educational activities of the national border guard agencies. In the context of information and communication technologies (ICT), emphasis is given to simulations and role-plays, and collaborative learning addressing challenges faced in European external border security and management. The eLearning courses and educational resources are main outcomes of development investments which are framed by ICT system development for supporting workflows and learning. Therefore, the setup of all existing courses will change during a transitional period phasing out from traditional classroom-based training delivery to facilitation of learning via the newly developed ICT environment [8].

The special attention of the border authorities of the EU countries today is attracted to the possibilities of educational web platforms, which are widely utilized in the training of 
personnel of the border agencies, namely: Web Platform Virtual Aula of the FRONTEX Agency; E-Net Web Platform of the CEPOL (The European Police College); EU Coast Guard Functions Training Portal (CGFTP); ILIAS Learning Platform of the EU Mission EUBAM (EU Border Assistance Mission to Moldova and Ukraine); Connect \& Learn platform of the UNHCR (The Office of the United Nations High Commissioner for Refugees); Global eLearning Program of the UNODC (United Nations Office on Drugs and Crime).

\subsection{Review of Modern Law-Enforcement Educational Web-Platforms with DL Border Guard Courses}

Virtual Aula Web Platform of the FRONTEX Agency. FRONTEX Agency created and continues to modernize its own virtual information and training platform Virtual Aula (Fig. 1). The slogan of the new platform for 2018 is Collaboration, Distribution, Training. In particular, this platform has become the focal point of cooperation for all border guard agencies, a means of obtaining operational information, implementing projects; distribution of all necessary resources: articles, multimedia materials, cases, means for informational education; a means of communicating in the community of specialists in the border guard sphere, creating groups for discussion of specific professional-oriented topics.

Distance courses developed by the FRONTEX Agency are interactive and allow for online meetings with teachers and colleagues, using Internet resources, accomplishing web quests, meeting in thematic chats, conducting project work, practicing various types and forms of learning activities. Nowadays, border guard agencies of EU countries are paying close attention to the development of DL in order to enhance their personnel professional competence. FRONTEX Agency, as an organization with responsibilities in the sphere of border and coast guards' training outlines the following advantages of this type of learning: first of all - DL can help develop and provide harmonized and cost-effective training products; facilitate development and implementation of professional standards; promote excellence in border and coast guard education and training. As a Learning Management System (LMS) FRONTEX Agency uses Moodle (Moodle Mobile), which is integrated into Virtual Aula platform; as for applications - Schengen Border Code eLearning Tool, WebEx, Skype; digital content: Adobe CC, Captivate, Moodle, MS Office, VR Suite, others. FRONTEX's eLearning Portfolio is composed of various online, blended and eLearning training courses.

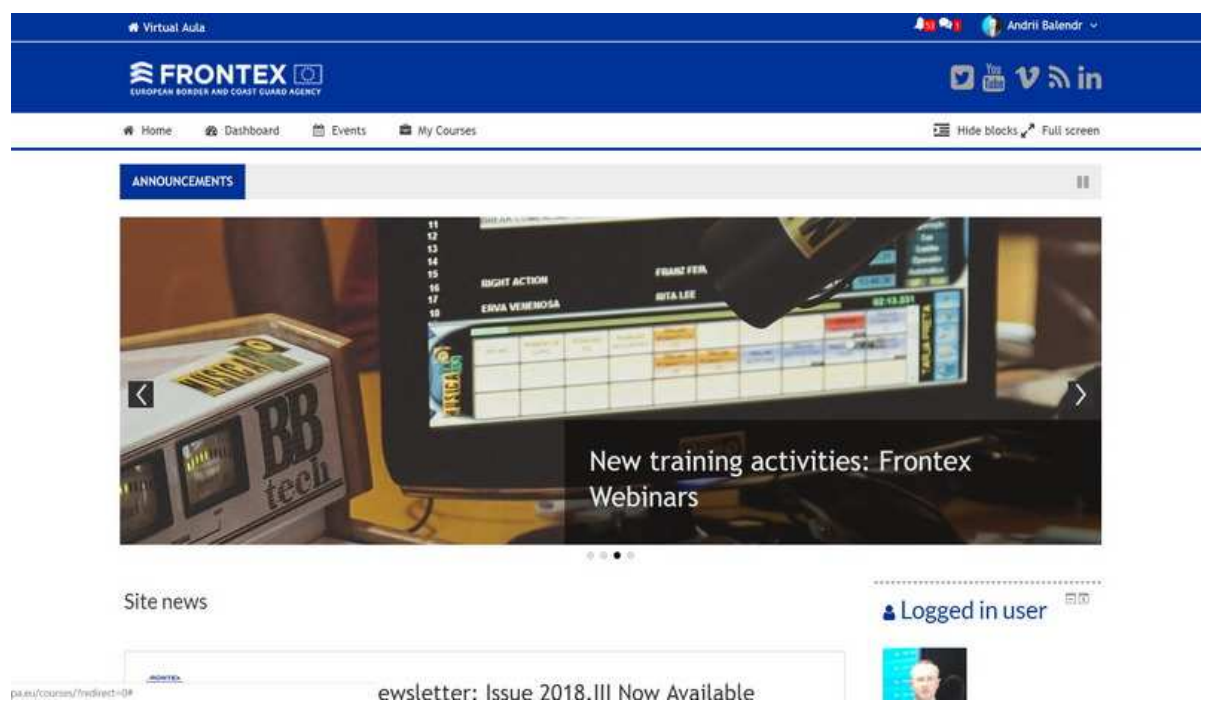

Fig.1 Virtual Aula Web Platform of the FRONTEX Agency 
CEPOL e-Net Learning Platform. The Learning Platform e-Net is a restricted CEPOL online training platform, in which registered users can use a wide range of information and training resources in the field of law enforcement activities such as courses, seminars, webinars, online modules and scientific journals (Fig.2). E-Net users can be law enforcement officers and educators in EU Member States, law enforcement officers and teachers from partner countries and organizations that have the right to apply for an online account online, scientists or academicians from universities or research institutes that are involved in research on law enforcement issues; employees of partner European institutions and agencies.

Law enforcers at e-Net courses have access to the LMS: web seminars, online training modules, courses, training resources for CEPOL course participants and CEPOL exchange programs; e-Library where researchers, scholars and research institutions share research projects or theses to support police education and contribute to all-European approach to policemen training; electronic journals that offer online access to a number of leading international articles on police science and education that address the prospects of research in law enforcement; exclusive presentations and video materials from CEPOL's scientific and research conferences. CEPOL is also implementing mobile-based DL training in European law enforcement communities. Benefits of learning with mobile devices: no additional equipment requirements, peripherals or special rooms (mobile phone only); training whenever possible (when available, immediately); self-regulation of the pace of learning, independent learning (independent of the tutors or moderators); anywhere and anytime (subject to connection to the Internet); obtaining the digital version of the certificate on the successful completion of the training course (with the results of training); effective self-diagnosis of the level of knowledge (type of testing is correct / incorrect).

CEPOL also uses a webinar system based on a comprehensive web-based learning platform. Features of a comprehensive training web platform include: coverage and dissemination of departmental highlights, webinar placement, user engagement to get acquainted with the complete list of possible webinars and registration for participation in them; organizing and moderating events that are "live" for collecting data from practitioners from EU Member States and organizations; recording and storing this information in the form of webinars; certificate of completion of courses. The CEPOL Integrated Learning Web Platform provides participants with conversations, a look at upcoming events and webinars, access to a database of recorded webinars, a certificate of completion of courses, a calendar with action reminders.

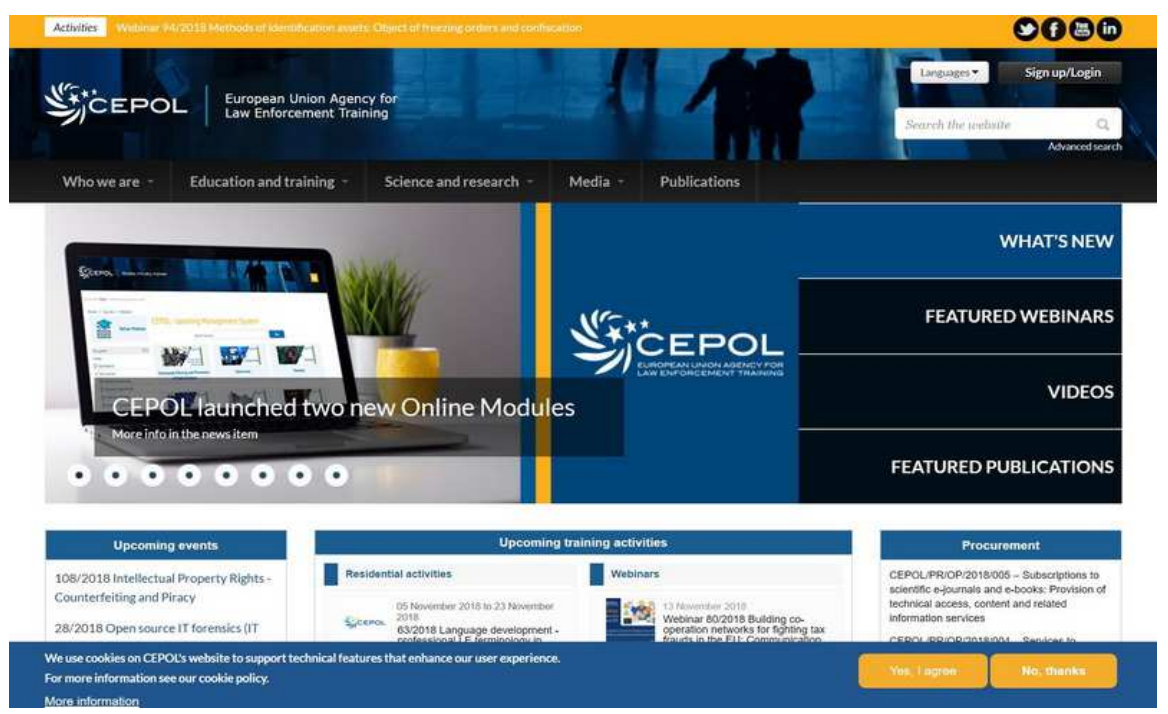

Fig.2 CEPOL e-Net Learning Platform 
Other promising directions of this platform are: further development of registration capabilities, tracking of statistics of views, feedback, certification, testing; extension of the training program with the help of webinars: preparation of multipliers, developers, validation of courses, their certification, improvement of interactivity of conducting webinars; increase in the audience of webinars among member countries [9].

The European Coast Guard Functions Training Network (ECGF Training Network) is a voluntary association of educational institutions providing education in the field of coast guard functions in the member states of the European Coast Guard Functions Forum (ECGFF). Membership is open to all officially recognized educational institutions involved in teaching, training and researching coast guard functions in the member states of the ECGFF. Tasks of the members are to seek to promote collaboration in the field of coast guard functions. The Coast Guard Training Portal contains information on trainings related to coast guard functions that are open to participants of other members of the Network, as well as information on exchange of opportunities, seminars, meetings, events and news on the training of coast guard functions. The training portal is also the main communication channel of the Network. The ECGF training portal is open to Coast Guard Training Network members who have access to public and registered information, as well as to other stakeholders and public users who have access to public information.

The access to the Forum's DL courses is continuous, comfortable and independent of the geographical area where the person is located. By means of a Virtual Campus, students may comfortably access, from any part of the world, a useful and dynamic learning experience, becoming the center of a totally personalized training process, assisted by a team of teachers that can offer the most innovative didactic resources and services. The methodology used for this course is based on technical aspects such as ICT and on constructivism concerning pedagogical aspects. It is a student-centered method that builds or increases students' knowledge together with the rest of students on the course who co-operate with each other or work as teams [10].

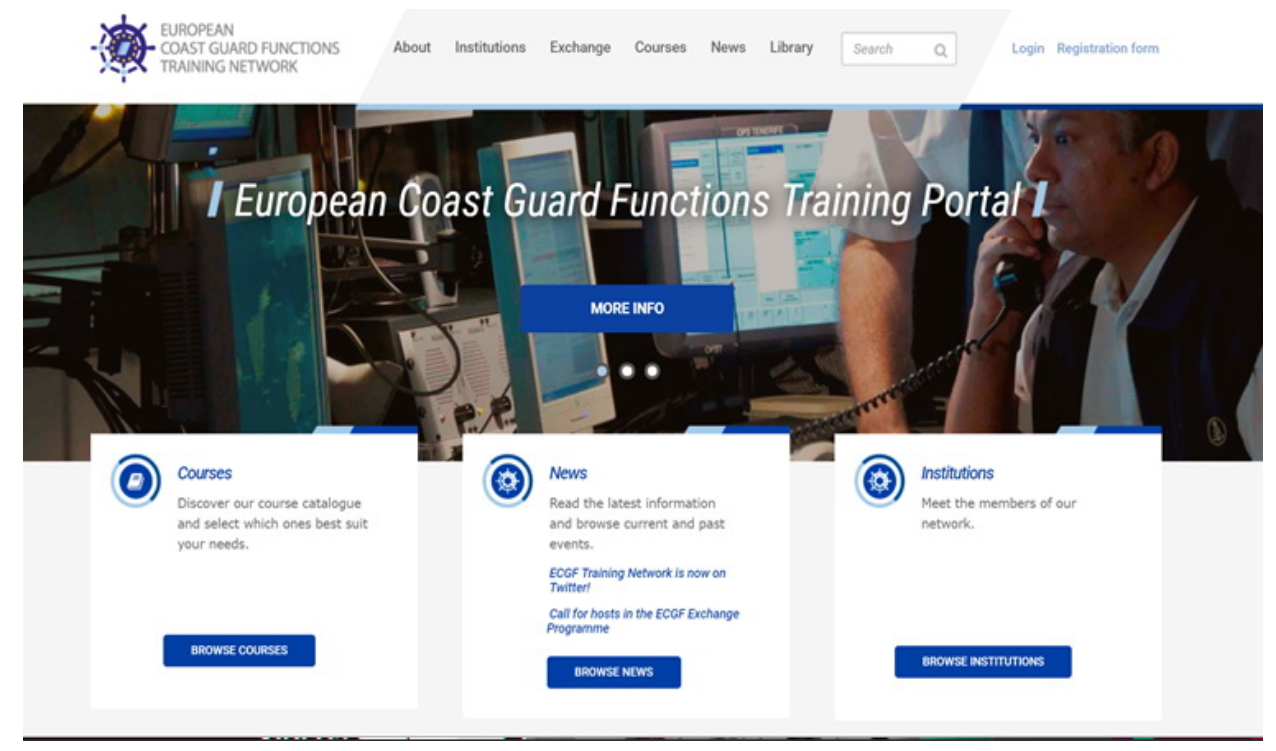

Fig.3 Coast Guard Training Portal for EU Coast Guard Agencies

Learning Web Platform ILIAS of the EU Mission EUBAM. The mission of EUBAM is to contribute to improvement of cross-border cooperation between border and customs agencies of Moldova and Ukraine. Thus, in order to organize effective informal and nonformal study of the personnel of Ukrainian and Moldavian state border protection authorities 
it was decided to develop and start conducting professional thematic training courses based on the ILIAS web platform (Fig.4). It was chosen because of its flexibility: possibilities to perform course management, organize material into learning modules, carry out assessment, work with portfolios, surveys, wikis, blogs etc. EU Mission EUBAM utilizes this platform to provide training for the personnel of the Border Guard Services (chiefs and deputies of the border guard divisions, international cooperation experts in border protection sphere, border guards, who serve at the first and second line of border checks at the border crossing points). The platform meets the demands of law-enforcement agencies on the account of reliable security level, possibility to change its interface, implement preferred training scenarios, integrate it with the agency's website or intranet, activate only certain modules, provide specified access and permissions for each student.

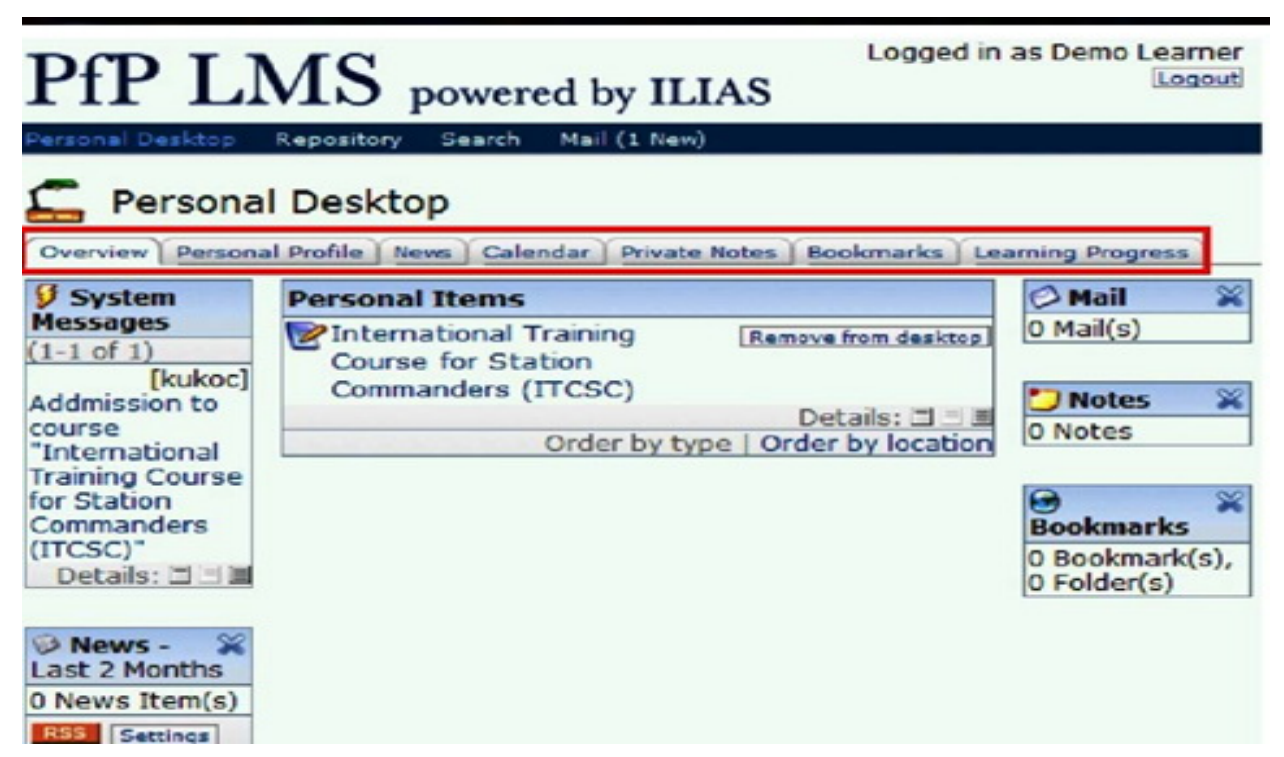

\section{Fig.4 Learning Web Platform ILIAS of the EU Mission EUBAM}

Learning Web Platform Connect and Learn of the UNHCR. The UNHCR is mandated to lead and co-ordinate international action to protect refugees and resolve refugee problems worldwide. Its primary purpose is to safeguard the rights and well-being of refugees. It strives to ensure that everyone can exercise the right to seek asylum and find safe refuge in another state, with the option to return home voluntarily, integrate locally or to resettle in a third country. It also has a mandate to help stateless people.

The UNHCR is actively implementing the latest approaches and tools for organizing DL. This organization is currently providing training to 16,000 people in 130 countries around the world. In this organization, its own eco-system of personnel training technology was developed (Fig.5). The LMS includes: webinars, online and offline media, mobile applications, self-learning tools, community of students. The main educational tools at UNHCR are webinars, DL courses, mixed learning courses, and software for independent study. In more than six decades, the agency has helped tens of millions of people restart their lives. Today, a staff of some 7,685 people in more than 125 countries continue to help some 33.9 million people.

The Global Learning Centre of UNHCR (GLC) manages and coordinates professional learning for UNHCR staff in several functional areas. The GLC strives to use innovative tools and approaches in adult learning, including various forms of DL. In particular, the GLC is seeking the options for creative solutions and learning products for DL [11]. 


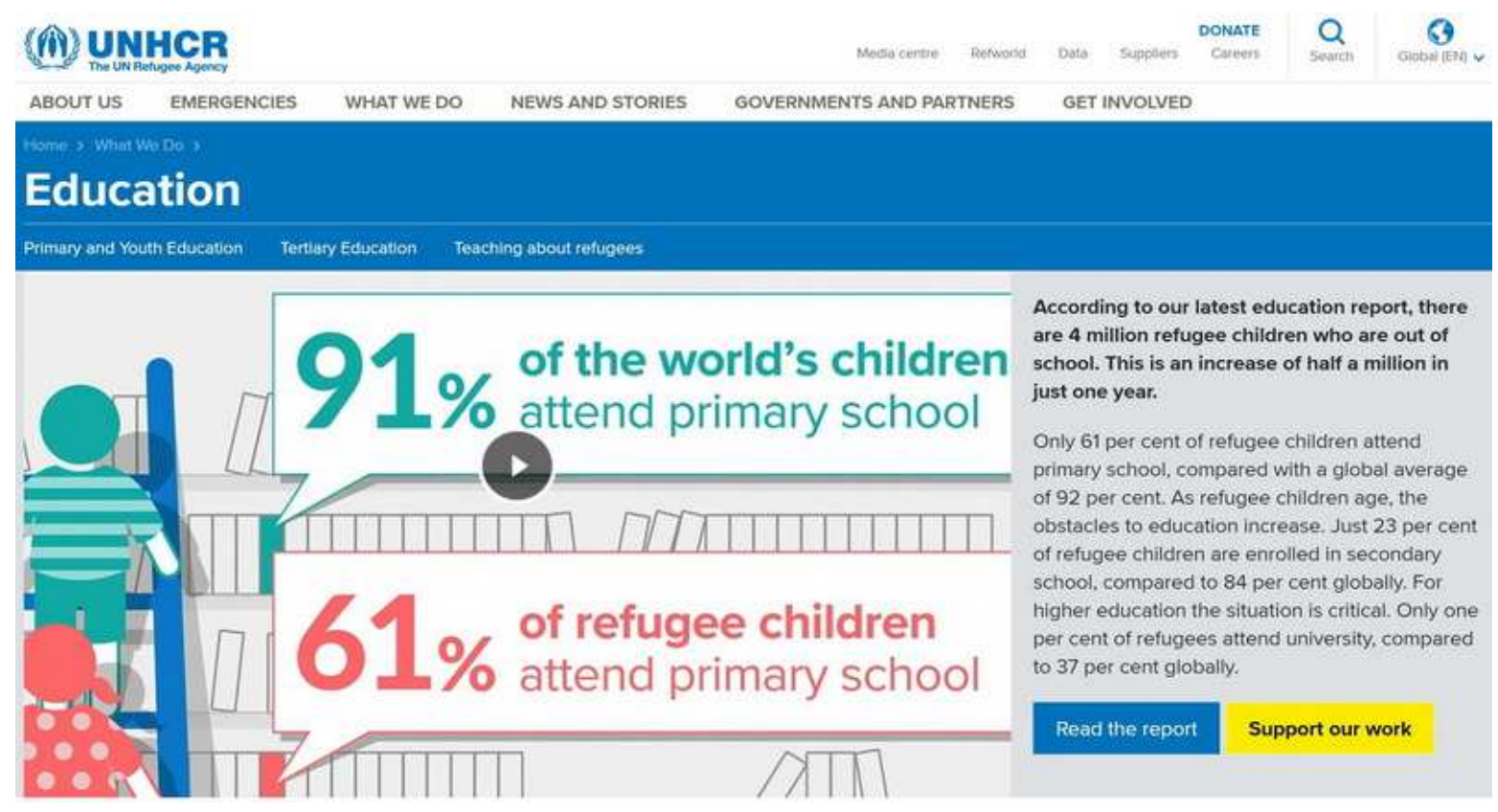

Fig.5 Learning Web Platform Connect and Learn of the UNHCR

The UNODC Global eLearning Programme. The UNODC Global eLearning Programme delivers up-to-date capacity building to Member State officials, thereby strengthening the capacity of governments to better meet human security needs and challenges. UNODC eLearning training is delivered online, offline and via mobile platforms and is available to anyone, in any working conditions. As part of its effort to raise awareness and knowledge in the important areas of Human Rights, HIV, AIDS and Anti-corruption, the UNODC Global eLearning Programme opened a "Public Area" within its platform containing these modules, making them available to the wider public (Fig.6).

UNODC eLearning in numbers: 231 training modules; 20 courses in 12 different languages; 3600 online users (25 in 2014); 1257 offline users; 16000 visits of the eLearning webpage (425 in 2014); 70000 hours of eLearning training delivered; 10 Mobile Training Units; 17 off-line servers; 7 customized Learning Management Systems; 5 training for trainers and eLearning Focal Persons; 600 helpdesk messages replied to and users assisted. The Global eLearning Programme is funded by the European Union and the Governments of Australia, Denmark, Japan, Norway, Sweden, the United Kingdom and the United States of America.

The Global eLearning Programme develops learning content in collaboration with UNODC senior and international experts. Learning modules are based on the consolidated UNODC experience in delivering capacity building worldwide following UN standards and best international practice. Current security and human threats such as transnational organized crime, illicit drugs, trafficking in persons and smuggling of migrants, and issues relating to border control, forensics and laboratories, controlled deliveries, security and travel documents, intelligence and human rights are covered [12]. 

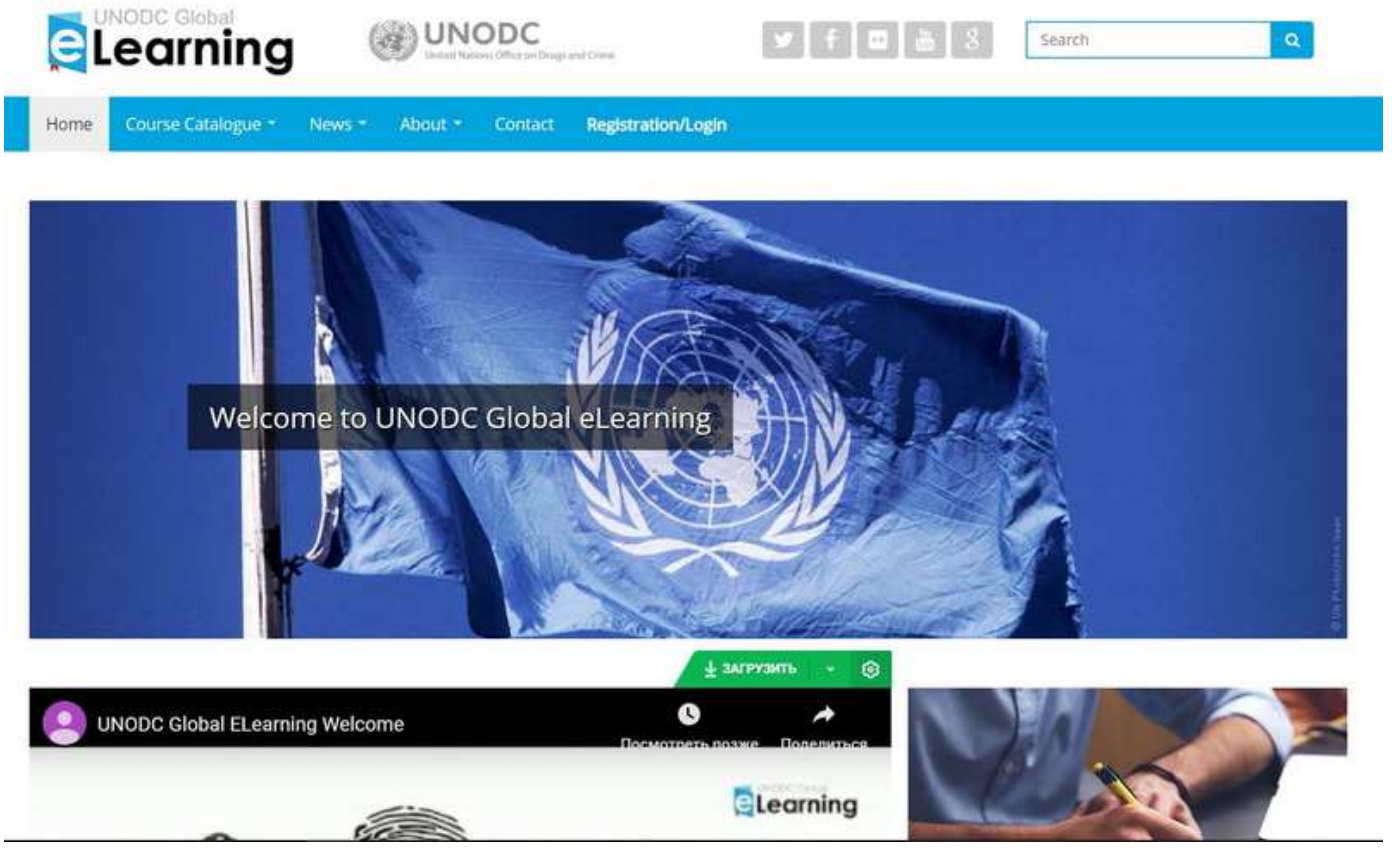

Fig.6 The UNODC Global eLearning Programme

\subsection{Comparison of DL courses of educational web platforms with border guard components in the $\mathrm{EU}$ countries}

The courses proposed by the reviewed web platforms are various and encompass different aspects of border guarding. From the list of law-enforcement DL courses presented on these web platforms we selected only those with direct border guard orientation (Table 1).

Table 1.

DL courses with border guard components based on the educational web platforms

\begin{tabular}{|c|l|}
\hline $\begin{array}{c}\text { EU Law- } \\
\text { enforcement web } \\
\text { platforms }\end{array}$ & \multicolumn{1}{|c|}{ DL courses for border guards } \\
\hline \multirow{5}{*}{$\begin{array}{c}\text { Virtual Aula } \\
\text { FRONTEX }\end{array}$} & $\begin{array}{l}\text { Basic Border Guard Training, Interoperability Assessment Program; Integrated Border } \\
\text { Management Capacity Building Project; Anti-trafficking in Human Beings; } \\
\text { Automated Border Management; Detection of False Documents; EUROSUR Training; } \\
\text { Observance of Fundamental Rights; Training of Marine Security Personnel; Mid-level } \\
\text { Management Course; Operational Briefings; Return Operations; Risk Analysis } \\
\text { Training; Schengen Evaluators Training; Training Delivery; Introduction to } \\
\text { Educational Technologies; English Language for Border Guards; Interagency } \\
\text { Cooperation; Integrated Border Management training; Canine Teams Training; } \\
\text { Sectoral Qualification Framework for Border Guarding; Schengen Border Code } \\
\text { eLearning Tool; 360-degree Interactive Video Tutorials }\end{array}$ \\
\hline e-Net CEPOL & $\begin{array}{l}\text { Counter-Terrorism; Crime prevention; Economic Crime; Cooperation with the EU; EU } \\
\text { policy; Human Rights; Law Enforcement Equipment; Training and Management; } \\
\text { Organized Crime; Research and Science; English for the Police }\end{array}$ \\
\hline ECGFF-training & $\begin{array}{l}\text { Inspection and Control of the Fish Industry and Activities Related to the Functions of } \\
\text { Coastal Protection; Search and Rescue Operations and Liquidation of Consequences of } \\
\text { portal }\end{array}$ \\
$\begin{array}{l}\text { Accidents; Emergency Situations at Sea; Marine Environment Protection; Marine } \\
\text { Monitoring and Supervision; Protection of the Sea Border; Maritime Customs; } \\
\text { Maritime Safety, Port and Vessel Safety, Fleet Management }\end{array}$ \\
\hline ILIAS EUBAM \\
$\begin{array}{l}\text { EU Legislature, and Schengen Law; Management and Leadership; Cross-Border } \\
\text { Investigation And Intelligence; Border Control and Implementation of Policies } \\
\text { Concerning Foreigners; Border Security; Border Control }\end{array}$ \\
\hline
\end{tabular}




\begin{tabular}{|c|l|}
\hline $\begin{array}{c}\text { Global eLearning } \\
\text { Programme UNODC }\end{array}$ & $\begin{array}{l}\text { Land Border Interdiction; Airport Interdiction; Seaport Interdiction Container Profiling } \\
\text { and Examination; Investigating Drug Organized Crime; Human Trafficking; } \\
\text { Smuggling of Migrants; Human Rights Security Document Examination; Investigating } \\
\text { Sexual Exploitation of Children for Frontline Officers; Firearms Trafficking }\end{array}$ \\
\hline \multirow{3}{*}{$\begin{array}{c}\text { Connect and Learn } \\
\text { UNHCR }\end{array}$} & $\begin{array}{l}\text { UNHCR Protection Training for European Border and Entry Officials; Human Rights } \\
\text { and Refugee Protection; Sphere in Action e-learning course; Humanitarian Charter and } \\
\text { Minimum Standards in Humanitarian Response; Protection Learning Programme, } \\
\text { Management and Leadership Learning Programme }\end{array}$ \\
\hline
\end{tabular}

So, comparison of DL courses of educational platforms with border guard components in the EU countries shows that the platform with the biggest number of border guard-oriented courses is Virtual Aula platform of FRONTEX Agency. Besides, the courses provided by Global eLearning Programme UNODC and Connect and Learn UNHCR have an international, global nature, whereas ILIAS EUBAM is highly specific, being offered only for the Ukrainian and Moldavian border guards.

In its turn, ECGFF-training portal is developed only for coast guard specialists, but eNet CEPOL platform has police and law-enforcement character. Therefore, the choice of the preferred web-platform and courses for border guards depends on the type of the professional duties, peculiarities of the border sectors (Land, Sea, Air). Nevertheless, the most flexible and effective, to our mind, is Virtual Aula platform by FRONTEX Agency, which offers courses for all the border guard specialties.

The conducted analysis of the EU Border Guard Agencies' DL platforms allows us to regard them as up-to-date and efficient, considering their large-scale usage. So, according to the web-based Training Needs Assessment of the EU (TNA, 2016) border guard agencies' DL systems development, the types of DL technologies used in EU border guard agencies comprise: Moodle about 50\%; ILIAS $18 \%$; and other $32 \%$. The study of the EU border guards who use LMS shows that half of the agencies' personnel have been using it for more than 5 years. As for the learners' devices used, it was found out that classroom educational technology is the most popular, mobile learning is of little use and specialized devices the same. It was found out that among the available types of educational devices and aids used by different border guard agencies, the most frequently used are: Computer workstations; Laptops; Tablets; Smartphones; Simulators; Virtual Reality goggles.

The most spread content digital learning resources are presentations, portable documents, HTML pages, but also SCORM packages. The most frequently used content digital learning resources are: Presentations and Portable documents (PDF); Web-based (HTML); SCORM learning; and also game-based, e-book and flash-based resources.

FRONTEX support in eLearning can be described in terms of low collaboration and support in the area of educational technology. Most of respondents would like to receive eLearning resources, know-how and trainer/teacher development from FRONTEX and a lot of respondents use technology enhanced courses/products. Popularity of different types of educational devices and aids used is the following: sharing eLearning resources is very popular, as well as sharing know-how; less popular is utilizing supporting instruments and course development and trainer/teacher development resources.

\subsection{Prospects of the Border Guards' DL Development in the EU Countries}

Today, the EU Border guards' training is provided by specialized national teaching staff and by FRONTEX Agency. Support is provided by external stakeholders such as the European Asylum Support Office, European Police School (CEPOL), UNHCR or NGOs. As the number of such courses for different categories of personnel is significant, not mentioning the language barrier, there is a need for unification of border guards' training in all EU countries. There have been determined five key factors that provide for the EU border guards' 
DL development.

The first is aligning all DL training courses to the Sectoral Qualification Framework Common Core Curricular for border guarding, to unify the skills and knowledge every European border guard has to be equipped with. Having implemented common educational standards into national curricula, border guards' learning processes should be guided in one direction, so that the personnel could gain professional competencies required for their border guard duties all over EU external borders.

The second factor is enhanced use of the Internet, social media and online demographics, podcast, blogs and RSS feeds. The role of communications has evolved and continues to progress with the considerable growth of social media and the continual advancement of mobile technologies, and the increasing availability of Wi-Fi means that the public now has the ability to access, customize and forward information however, wherever and whenever they want. Individuals can choose to receive information and instant updates on topics they have decided are beneficial and relevant to them. Use of social media tools for engagement and information sharing purposes is an integral part of the new content management system, hosting and monitoring services [8].

The third key factor is elaborating and implementing a common informational and educational web-platform, which would encompass information about border guard training events and projects, in order to provide to EU border guard agencies, FRONTEX Affiliate Academies, training coordinators, instructors, teachers and project assistants a clear view of the overall picture of what is conducted in EU countries in the sphere of border guard training and provide possibilities for the personnel to take certain DL courses, both in English and in national languages.

The fourth factor is organizing specialized training for the border guards, course designers, trainers and other specialists from EU countries regarding competence formation in DL using and management, including creation of webinars and courses. On completion of such courses a person should be able to: differentiate between systems and technologies available for DL, compare their suitability, implement, supervise and evaluate their use and results; take the initiative to identify, assess and address personal and professional development requirements for themselves and others utilizing a range of DL resources and contexts; apply distance learning concepts and tools in course design and learning resources development.

The fifth factor is developing common eLearning tools and programs for representatives of different EU countries, in order to involve participating border guards in informal and nonformal types of learning; conducting synchronous (video) training sessions, webinars, interactive presentations, uploading information resources according to their didactic possibilities and depending on the purposes of studying. More attention is paid to learning through interaction and collaboration. In order to provide the opportunity for border guards to exchange experience in solving professional issues we have to pay more attention to the development of professional vocabulary in foreign language classes and use authentic audio and video materials to improve the border guards' listening comprehension skills, widely using eLearning tools for conducting all types of classes and finding ways to motivate the personnel.

\section{CONCLUSIONS AND PROSPECTS FOR FURTHER RESEARCH}

An important task the border authorities of the EU countries face nowadays is development of the system of training, retraining and advanced training of the personnel. One of the options for solving this problem is the active use of the possibilities of foreign experience, and one of the main issues that need to be addressed is the modernization of the 
national border guards' professional training technologies, namely: creation of modern educational tools based on virtual, augmented and mixed reality; use of educational products for independent study of border guards; modernization of the existing DL system for the creation of a modern interactive system of personnel training (conducting online meetings, organization of project work, placement of educational video material, conducting web quests, providing the opportunity to communicate in professional chats); considering mobile training for border guards; participation of Border Educational Institutions in the Network of EU Border Guard Partnership Academies.

The special attention of the border authorities of the EU countries today is attracted to the possibilities of educational web platforms, which are widely utilized in the training of personnel of the border agencies, namely: e-Net web platform of the CEPOL; web platform Virtual Aula of the FRONTEX Agency; CGFTP; ILIAS Learning Platform of the EU Mission EUBAM; Connect \& Learn platform of the UNHCR; Global eLearning Program of the UNODC. The authors have also conducted a comparative analysis of DL courses of educational platforms with border guard components in the EU countries, which showed that the platform with the biggest number of border guard-oriented courses is Virtual Aula platform of FRONTEX Agency.

The quantitative analysis of the EU border guard agencies' DL according to the webbased Training Needs Assessment of the EU border guard agencies' DL systems development proved that the EU border guard agencies mostly use LMS Moodle; as for the educational devices and aids, computer workstations and laptops are used. The most spread content digital learning resources are presentations; the most frequently used content is digital learning resources and presentations. All the above mentioned has prompted us to formulate the prospects of the border guards' DL development in the EU countries, based on 5 key factors: aligning all DL training course to the Sectoral Qualification Framework and Common Core Curricular for border guarding, unification of the skills and knowledge of European border guards; enhanced use of the Internet and social media; introduction of a common educational web-platform; organizing specialized training for the specialists in DL use and management, and developing common eLearning tools and programs.

\section{REFERENCES (TRANSLATED AND TRANLITERATED)}

[1] A. Sarkar, Vocational education and training through open \& distance learning mode: Prospects and challenges. International Journal of Applied Research, 1 (13), 592-594. 2015. (in English)

[2] P. Andriyanov, Use of modern educational technologies in the field of military education. Distance learning - problems and decisions. Border Security and Management, 1(6), 7-14. 2016. doi 10.17770/bsm.v1i6.1696 (in English)

[3] M. Spridzāns, and J. Pavlovičs, Perspectives on Developing E-Learning at the State Border Guard College of the Republic of Latvia. Border Security and Management, 1(6), 112-122. 2016. doi 10.17770/bsm.v1i6.1707. (in English)

[4] G. Stevens, Distance learning for technical and vocational education in Sub-Sahara Africa: challenges and opportunities. Washington, DC: World Bank. 2001. [online]. Available: http://documents.worldbank.org/curated/en/107121468201609489/Distance-learning-for-technical-andvocational-education-in-Sub-Sahara-Africa-challenges-and-opportunities. (in English)

[5] A. Balendr, O. Komarnytska, I. Bloshchynskyi, O. Didenko, Information and communication technologies in foreign languages training of the border guards in the European Union Countries. Information Technologies and Learning Tools, 67(5), 56-71. 2018. (in Ukrainian)

[6] A. Balendr, Designing Professionally Oriented Training Courses for Border Guards in Accordance with the Sectoral Qualifications Framework based on the Virtual Aula Platform. Information Technologies and Learning Tools, 63(1), 68-80. 2018. (in Ukrainian)

[7] I. Bloshchynskyi, Enhancement of Cadets' Practical Training at the National Academy of the State Border Guard Service of Ukraine named after Bohdan Khmelnytskyi. Science and Education, (4), 5-10. 2017. (in English)

[8] FRONTEX Training Needs Assessment 2016 Report. Warsaw. 2016. [online]. Available: 
https://frontex.europa.eu/assets/Publications/Training/Training_Needs_Assesment_2016_report.pdf. (in English)

[9] European Union Agency for Law Enforcement Training [CEPOL]. Education and Training. 2018. [online]. Available: https://www.cepol.europa.eu/education-training. (in English)

[10] European Coast Guard Functions Training Network [ECGFTN]. Coast Guard Functions Training Portal. 2018. [online]. Available: http://ecgff-trainingportal.eu/pages/49-coast-guard-functions-training-portal. (in English)

[11] Global Learning at UNHCR - ICELW. UNHCR Global Learning Centre (GLC) Division of Human Resources Management UNHCR HQs Global Service Centre (GSC) [PowerPoint presentation]. 2011. [online]. Available: https://www.icelw.org/proceedings/2011/Slides/Ralston.ppt. (in English)

[12]. Newsletter on the UNODC Global eLearning Programme (GLOU61). Annual Newsletter, (5). 2015. [online]. Available: https://www.unodc.org/documents/elearning/2016.03.01_NewsLetter-Annual2015.pdf. (in English).

Text of the article was accepted by Editorial Team 03.12.2018

\section{РОЗВИТОК ДИСТАНЦИЙНОГО НАВЧАННЯ ПРИКОРДОННИКІВ У КРАЇНАХ ЄВРОПЕЙСЬКОГО СОЮЗУ}

\section{Балендр Андрій Васильович}

кандидат педагогічних наук, доцент,

доцент кафедри англійської мови факультету іноземних мов та гуманітарних дисциплін

Національна академія Державної прикордонної служби України ім. Богдана Хмельницького,

м. Хмельницький, Україна

ORCID ID 0000-0003-4610-2830

drbalen@i.ua

\section{Корольов Василь Олександрович}

кандидат юридичних наук, доцент кафедри спеціальних дисциплін

Національна академія Державної прикордонної служби України ім. Богдана Хмельницького,

м. Хмельницький, Україна

ORCID ID 0000-0002-8342-7557

docentpvu@i.ua

\section{Адамчук Олександр Валерійович}

кандидат психологічних наук, начальник факультету охорони та захисту державного кордону Національна академія Державної прикордонної служби України ім. Богдана Хмельницького, м. Хмельницький, Україна

ORCID ID 0000-0003-0280-6334

alexadamchuk@ukr.net

\section{Якимчук Анатолій Володимирович}

кандидат психологічних наук, викладач кафедри тактики прикордонної служби

Національна академія Державної прикордонної служби України ім. Богдана Хмельницького,

м. Хмельницький, Україна

ORCID ID 0000-0002-2729-8201

anatoliy_yakimch@ukr.net

\section{Сінкевич Сергій Валентинович}

кандидат педагогічних наук, доцент, доцент кафедри загальновійськових дисциплін Національна академія Державної прикордонної служби України ім. Богдана Хмельницького, м. Хмельницький, Україна

ORCID ID 0000-0001-5838-2177

sinkevich76@i.ua

\section{Блощинський Ігор Григорович}

доктор педагогічних наук, професор,

начальник кафедри перекладу факультету іноземних мов та гуманітарних дисциплін

Національна академія Державної прикордонної служби України ім. Богдана Хмельницького,

м. Хмельницький, Україна

ORCID ID 0000-0003-1925-9621

i.bloshch@gmail.com 


\begin{abstract}
Анотація. У статті проаналізовано розвиток дистанційного навчання (ДН) у рамках підготовки фахівців з охорони кордону в країнах Європейського Союзу (СС). Ірунтовно розкрито теоретичні та практичні аспекти, сучасний стан та особливості розвитку ДН у прикордонних відомствах країн ЄС. Особливу увагу було приділено можливостям навчальних веб-платформ, які широко використовуються в навчанні персоналу прикордонних відомств, а саме: веб-платформі Virtual Aula Агентства FRONTEX; e-Net вебплатформі CEPOL; веб-платформі CGFTP; навчальній платформі ILIAS Miciї CC EUBAM; веб-платформі Connect \& Learn UNHCR; програмам електронного навчання UNODC. Автори також провели порівняльний аналіз курсів ДН освітніх веб-платформ із прикордонною тематикою в країнах $\mathrm{CC}$ i довели, що веб-платформа 3 найбільшою кількістю курсів, орієнтованих на підготовку фахівців 3 охорони кордону - це віртуальна платформа Virtual Aula Агентства FRONTEX. Пропозиції щодо розвитку ДН та перспективні напрями, засновані на досвіді, отриманому під час впровадження ДН у систему підготовки фахівців 3 охорони кордону і підтверджені результатами опитування, наведені у висновках до статті 3 метою сприяння вдосконаленню роботи системи ДН прикордонних відомств. Перспективи розвитку системи ДН фахівців 3 охорони кордону складаються з п'яти ключових факторів: узгодження всіх навчальних курсів ДН відповідно до Галузевої рамки кваліфікацій та Уніфікованих програм підготовки в галузі охорони кордону: уніфікація навичок та знань європейських фахівців з охорони кордону; посилення використання можливостей мережі Інтернет та соціальних мереж; впровадження спільних навчальних веб-платформ; організація спеціалізованої підготовки фахівців з використання та управління ДН; і п'ятий фактор - розробка спільних освітніх інструментів та програм електронного навчання.
\end{abstract}

Ключові слова: підготовка фахівців з охорони кордону; дистанційне навчання; освітні вебплатформи; країни Європейського Союзу.

\title{
РАЗВИТИЕ ДИСТАНЦИОННОГО ОБУЧЕНИЯ ПОГРАНИЧНИКОВ В СТРАНАХ ЕВРОПЕЙСКОГО СОЮЗА
}

\section{Балендр Андрей Васильевич}

кандидат педагогических наук, доцент,

доцент кафедры английского языка факультета иностранных языков и гуманитарных дисциплин Национальная академия Государственной пограничной службы Украины им. Богдана Хмельницкого, г. Хмельницкий, Украина

ORCID ID 0000-0003-4610-2830

drbalen@i.ua

\section{Королев Василий Александрович}

кандидат юридических наук, доцент кафедры специальных дисциплин

Национальная академия Государственной пограничной службы Украины им. Богдана Хмельницкого, г. Хмельницький, Украина ORCID ID 0000-0002-8342-7557

docentpvu@i.ua

\section{Адамчук Александр Валерьевич}

кандидат психологических наук, начальник факультета охраны и защиты государственной границы Национальная академия Государственной пограничной службы Украины им. Богдана Хмельницкого, г. Хмельницкий, Украина

ORCID ID 0000-0003-0280-6334

alexadamchuk@ukr.net

\section{Якимчук Анатолий Владимирович}

кандидат психологических наук, начальник факультета охраны и защиты государственной границы Национальная академия Государственной пограничной службы Украины им. Богдана Хмельницкого, г. Хмельницький, Украина

ORCID ID 0000-0002-2729-8201

anatoliy_yakimch@ukr.net 


\section{Синкевич Сергей Валентинович}

кандидат педагогических наук, доцент, доцент кафедры общевойсковых дисциплин

Национальная академия Государственной пограничной службы Украины им. Богдана Хмельницкого, г. Хмельницький, Украина

ORCID ID 0000-0001-5838-2177

sinkevich76@i.ua

\section{Блощинский Игорь Григорьевич}

доктор педагогических наук, профессор,

начальник кафедры перевода факультета иностранных языков и гуманитарных дисциплин

Национальная академия Государственной пограничной службы Украины им. Богдана Хмельницкого,

г. Хмельницкий, Украина

ORCID ID 0000-0003-1925-9621

i.bloshch@gmail.com

Аннотация. В статье проведен анализ развития дистанционного обучения (ДО) в рамках подготовки специалистов по охране границы в странах Европейского Союза (ЕС). Детально раскрыто теоретические и практические аспекты, современное состояние и особенности развития ДО в пограничных ведомствах стран ЕС. Особое внимание было уделено возможностям учебных веб-платформ, которые широко используются в обучении персонала пограничных ведомств, а именно: веб-платформе Virtual Aula Агентства FRONTEX; е-Net веб-платформе CEPOL; веб-платформе CGFTP; учебной платформе ILIAS Миссии EC EUBAM; веб-платформе Connect \& Learn UNHCR; программам электронного обучения UNODC. Авторы также провели сравнительный анализ курсов ДО образовательных веб-платформ с пограничной тематикой в странах ЕС и доказали, что вебплатформа с наибольшим количеством курсов, ориентированных на подготовку специалистов по охране границы - это виртуальная платформа Virtual Aula Агентства FRONTEX. Предложения по развитию ДО и перспективные направления, основанные на опыте, полученном при внедрении ДО в систему подготовки специалистов по охране границы и подтвержденные результатами опроса, представлены в выводах к статье с целью содействия совершенствованию работы системы ДО пограничных ведомств. Перспективы развития системы ДО специалистов по охране границы состоят из пяти ключевых факторов: согласование всех учебных курсов ДО с Отраслевой рамкой квалификаций и Унифицированных программ подготовки в области охраны границы: унификация навыков и знаний европейских специалистов по охране границы; усиление использования возможностей сети Интернет и социальных сетей; внедрение совместных учебных вебплатформ; организация специализированной подготовки специалистов по использованию и управления ДО; и пятый фактор - разработка совместных образовательных инструментов и программ электронного обучения.

Ключевые слова: подготовка специалистов по охране границы; дистанционное обучение; образовательные веб-платформы; страны Европейского Союза.

\section{(cC) BY-NC-SA}

This work is licensed under Creative Commons Attribution-NonCommercial-ShareAlike 4.0 International License. 